Журнал «Герспективитаінноваціїнауки»

(Серія «Гедагогіка», Серія «Гиихологія»), Серія«Медицина»

№5(5) 2021

УДК 373.5.09

https://doi.org/10.52058/2786-4952 -2021-5(5)-228-238

Гусак Валентина Миколаївна кандидат педагогічних наук, доцент кафедри педагогіки й андрагогіки, Комунальний заклад «Житомирськийобласний інститут післядипломної педагогічної освіти» Житомирської обласної ради, БОС 1/10 кв. 29, м. Житомир, 10004, тел.: (067) 269-73-82 e-mail: vgusak@i.ua, https://orcid.org/0000-0002-6495-9427

\title{
ПРОГРАМА ВИХОВАННЯ В ОСВІТНІЙ СИСТЕМІ ШКОЛИ: КЛЮЧОВІ ПРІОРИТЕТИ ТА ЗМІСТ
}

Анотація Стаття присвячена проблемі удосконалення якості процесу виховання шляхом розроблення програми виховання. Розглянуто сучасні засади виховання відповідно до формули Концепції «Нова українська школа».

У результаті дослідження викликів, що виникли в процесі практики реформування освітнього процесу в закладах освіти було виділено найбільш складні проблеми, а саме: девальвація цінностей; низька мотивація учнів; відсутність єдиної стратегії виховання у закладі освіти; залишилася традиція рутинних заходів, що проводяться задля заходів, без усілякої системи та зв'язку $з$ принципами дитиноцентризму; недостатній рівень партнерської взаємодії між учасниками освітнього процесу; домінування кількості заходів над їх якістю тощо.

На підставі чинного законодавства обгрунтовано актуальність розроблення програми виховання в окремо взятій школі як засобу підсилення якості освітнього процесу під час уроку на принципах наскрізності.

Виділено ключові поняття та уточнено їх зміст: виховання, программа виховання, проектування, дитиноцентризм, наскрізність, цінності.

Зосереджено увагу на розкритті поняття «програма виховання», яке розуміється як системне уявлення про умови досягнення виховних цілей, що виражається в послідовному викладі змісту виховного процесу, механізмах його реалізації і основних індикаторах становлення особистості в контексті реалізації моделі випускника нової української школи. Цінність, за філософським словником соціальних термінів, визначаємо як «духовне формоутворення, що існує через моральні та естетичні категорії теоретичної системи, утопічні образи, суспільні ідеали та інше, і виступає критерієм оцінки дійсності людиною та джерела смислоутворюючої основи людського вчинку.

Визначено основні компоненти змісту програми виховання та їх сутність, а саме: особливості виховного процесу: мету і завдання виховання види, форми та зміст діяльності; основні напрями самоаналізу якості змісту виховного процесу 
Ключові слова: освітній процес, виховання, программа виховання, проєктування, дитиноцентризм, наскрізність, цінності.

Husak Valentyna Mykolayivna Candidate of Pedagogical Sciences, Associate Professoro fthe Departmentof Pedagogyand Andragogy, Zhytomyr Regional Institute of Postgraduate Pedagogical Education of the Zhytomyr Regional Council, BOS 1/10 sq. 29, Zhytomyr, 10004, tel: (067) 269-73-82, e-mail: vgusak@i.ua, https://orcid.org/0000-0002-6495-9427

\section{EDUCATION PROGRAM IN THE SCHOOL EDUCATIONAL SYSTEM: KEY PRIORITIES AND CONTENT.}

Abstract. The article is devoted to the problem of improving the quality of the educational process by developing an educational program. Modern principles of education in accordance with the formula of the Concept "New Ukrainian School" are considered.

As a result of the study of the challenges that arose in the process of reforming the educational process in educational institutions, the most difficult problems were identified, namely: devaluation of values; low motivation of students; lack of a unified strategy of education in the educational institution; the tradition of routine activities for events, without any system and connection with the principles of childcenteredness, has remained; insufficient level of partnership between participants in the educational process; dominance of the number of measures over their quality, etc.

Based on the current legislation, the relevance of developing a program of education in a particular school as a means of strengthening the quality of the educational process during the lesson on the principles of end-to-end.

The key concepts are highlighted and their content is clarified: education, education program, design, child-centeredness, pervasiveness, values.

The focus is on the disclosure of the concept of "education program", which is understood as a systematic view of the conditions for achieving educational goals, expressed in a consistent presentation of the educational process, mechanisms of its implementation and key indicators of personality development in the context of the new Ukrainian school graduate model. Value, according to the philosophical dictionary of social terms, is defined as "spiritual formation that exists through moral and aesthetic categories of theoretical system, utopian images, social ideals and more, and serves as a criterion for assessing human reality and the source of meaning of human action.

The main components of the content of the educational program and their essence are determined, namely: features of the educational process: the purpose and objectives of education, types, forms and content of activities; main directions of self-analysis of the quality of the content of the educational process.

Keywords: educational process, education, education program, design, childcenteredness, pervasiveness, values. 
Журнал«Герспективитаінновації наукиљ

(Серія«Гедагогіка», Серія«ГЕихологія», Серія «Медицин»

№5(5) 2021

Постановка проблеми. Переміна парадигми розвитку світової цивілізації актуалізувала проблему підготовки людини для життя в умовах динамічних трансформацій. Орієнтація України на європейські стандарти відкрила нові перспективи реформування освітньої галузі відображені в основних положеннях Законів України «Про освіту»(2017), «Про повну загальну середню освіту» (2020), Концепції реалізації державної політики у сфері реформування загальної середньої освіти «Нова українська школа» (2016), Державного стандарту базової середньої освіти (2020).

Квінтесенцією змін упродовж останніх років стала сучасна українська школа. Серед першорядних проблем домінуючими стали ті, що стосуються підвищення якості виховання, яке набуло принципово нових філософських ідей, грунтується на принципах наскрізності, дитиноцентризму та має глибинну ціннісно-світоглядну домінанту [1].

Реалії сьогодення свідчать про те, що школа занурена у процес глибинних трансформацій, який характеризується розривом старих традицій (шаблонів) та активним пошуком інноваційних шляхів оновлення освітнього процесу, зіштовхнулася зі складними проблемами реалізації завдань виховання як складової освітнього процесу.

Під час роботи курсів підвищення кваліфікації педагогічних фахівців різних категорій нами було проведено дослідження викликів, які має школа. У результаті зафіксовано найбільш складні, а саме: девальвація цінностей, низька мотивація учнів, відсутність єдиної стратегії виховання у закладі освіти, залишилася традиція рутинних заходів, що проводяться задля заходів, без усілякої системи та зв'язку з принципами дитиноцентризму,недостатній рівень партнерської взаємодії між учасниками освітнього процесу, домінування кількості заходів над їх якістю тощо. Зазначені проблеми пояснюються складною внутрішньою перебудовою змісту виховання, його периферійністю на тлі гіпертрофованого спрямування на сферу знань. Незважаючи на те, що виховний процес $є$ невід'ємною складовою освітнього процесу, його мета та принципи чітко означені у Державному стандарті базової середньої освіти, результати опрацювання свідчать про те, що розробники здебільшого акцентують увагу на характеристиці змісту навчання, вимогах до його обов'язкових результатів за освітніми галузями, а виховання як наскрізний компонент освітнього процесу розглядається досить побіжно.

У зв'язку з цим, особливої актуальності набуває проблема посилення виховної складової як цілеспрямованої наскрізної діяльності усіх суб'єктів освітнього процесу щодо всебічного розвитку школяра як цілісної особистості в духовному, інтелектуальному, емоційному, фізичному, моральному i психічному проявах; формуванні ним базових компетентностей, необхідних для самореалізації в XXI ст.

Очевидним $є$ той факт, що зазначені проблеми не можуть бути вирішені школою відразу і швидко. Однак, вважаємо, що першим кроком систематизації та прогнозування якості складових освітнього процесу школи та підсилення 
його виховної компоненти може статипрограма виховання 3 концептуальною основою, яка виражатиме системне бачення, тобто візуалізацію майбутнього, у якому хоче опинитися школа через певний період часу на шляху реалізації моделі випускника, заданої Концепцією НУШ. Щоб досягти означеної мети, усі учасники освітнього процесу мають розуміти та дотримуватися наскрізних цінностей [6], бути обізнаними з метою, завданнями та змістом виховання, напрямах його реалізації в кожній окремі школі. А також бути гнучкими та готовими до оперативних змін відповідно до нових викликів та партнерської взаємодії у створенні затребуваних ресурсів. На основі основних положень програми ви ховання школа здійснює загальне планування, а класні керівники 3 учнівською спільнотою класу. Ефективність впровадження програми може стати індикатором системності на навскрізності виховання в окремій школі. Право на ii розроблення обумовлене академічною автономією освітнього закладу, яку школа отримала відповідн до положень Закону України «Про освіту» [5].

Аналіз останніх досліджень і публікацій. Проблеми виховання широко досліджуються представниками вітчизняної та закордонної науки та практики. Основні засади гуманістичної освіти розроблено в працях Ш. Амонашвіллі, I. Зязюна, В. Сухомлинського, К. Роджерса, Я. Корчака. Філософія дитино центризму обгрунтована В. Кременем. В умовах реформування актуальності набуваютьнаукові доробки I. Беха (особистісно орієнтоване виховання), О. Вишневського (виховання на цінностях та національно-патріотичний аспект), Т. Гавлітіної (наскрізне виховання цінностей у Новій українській школі), А. Гжегоржика (філософія та зміст цінностей), О. Захаренка (авторська виховна система на принципах гуманізму), О. Сухомлинської (християнські та моральні цінності) та ін. Цілісну концепцію ціннісно-смислового змісту українського виховання розкрили у Програмі «Нова українська школа» у поступі до цінностей І. Бех, К. Журба. С. Кириленко, Л. Корецька та ін.

Основи програмування процесу виховання розглянуто у працях Н. Селеванової, П. Степанова,Н. Щуркової.

Однак, проблема визначення ключових пріоритетів програми виховання у контексті розбудови нової української школи у вітчизняній науці недостатньо досліджена та потребує уточнення ії змістового наповнення.

Мета статті - дослідження особливостей розроблення програми виховання в умовах сучасної школи, визначення ключових пріоритетів та обгрунтування вимог до її змістового наповнення.

Виклад основного матеріалу. Реалізація мети нашого дослідження потребує уточнення ключових термінів, які є основою сучасного виховання.

О. Вишневський визначає виховання як партнерську взаємодію педагогів та учнів у процесі спільної діяльності, що спрямована на розвиток у вихованців кращих рис людини і громадянина [2].

Виходячи з гуманістичної парадигми освіти, дитина розглядається як унікальна і неповторна цінність, що має індивідуальні особливості розвитку. 
Виходячи з цього, виховання спрямоване на розкриття потенціалу особистості, на створення умов для розвитку у неї кращих моральних і громадянських якостей. Така установка означає впевненість у тому, що кожна дитина заслуговує на повагу, визнання за кожним учнем індивідуальних поглядів, інтересів, суджень. У кожній особистості слід бачити ціль та унікальність.

Виховання в освітньому процесі розуміємо як цілеспрямовану діяльність, що здійснюється в системі освіти, орієнтована на створення умов для розвитку духовності зростаючої особистості на основі загальнолюдських і національних цінностей, надання допомоги в життєвому самовизначенні, громадянській i професійній компетентності та цілісній самореалізації [8].. Відповідно метою вихованняє розвиток духовно-моральної особистості, здатної бути повноцінним суб’єктом суспільно значущих соціальних взаємин.

Нова українська школа розглядає дитиноцентризм як максимальне наближення навчання і виховання конкретної дитини до іiї сутності, здібностей і життєвих планів[6,7].

Відповідно до філософського словника соціальних термінів, цінністю $є$ духовне формоутворення, що існує через моральні та естетичні категорії теоретичної системи, утопічні образи, суспільні ідеали та інше, і виступає критерієм оцінки дійсності людиною та джерела смислоутворюючої основи людського вчинку. У психології особистості загальновживаним є термін «особистісні ціннісні», що засвідчує факт освоєння суб'єктом соціальних зв'язків та ставлень, тобто освоєння ним суспільних цінностей, які стають унормованим утворенням [7].

У робочому варіанті розуміємо програму виховання як системне уявлення про умови досягнення виховних цілей, що виражається в послідовному викладі змісту виховного процесу, механізмах його реалізації і основних індикаторах становлення особистості в контексті реалізації моделі випускника нової української школи.

Беремо до уваги думку про те, що виховання - це цілеспрямована діяльність, яка здійснюється в системі освіти, орієнтована на створення умов для розвитку духовності зростаючої особистості на основі загальнолюдських, національних цінностей, надання допомоги в життєвому самовизначенні, громадянській і професійній компетентності та цілісній самореалізації. [9].

Фактично програма виховання - це зміст необхідної і достатньої діяльності педагогічної спільноти щодо виховного результату, який заданий виховною метою. Її реалізація покликана забезпечувати позитивну динаміку розвитку особистості учня, а саме: засвоєння ним основних суспільних норм, вироблених на основі системи цінностей; позитивне ставлення до суспільних цінностей демократичного суспільства та отримання досвіду соціальної поведінки у застосуванні сформованих знань і ставлень на практиці в умовах свідомого вибору[11].

Розглянемо деякі особливості розроблення програми виховання. Цитування думки видатного українського психолога Г.С. Костюка про те, що 
виховувати - означає проектувати поступове становлення якостей особистості та керувати здійсненням накреслених проектів [8], дозволяє міркувати про те, щоконструювання програми виховання може розглядатися як процес педагогічного проєктування.Таким чином, робота над проектом складатиме перелік наступних дій:

- виявлення проблем виховання в окремо визначеній школі;

- постановка завдань;

- визначення умов їх вирішення;

- прогнозування результату;

- планування діяльності з досягнення визначеної мети;

- іï реалізація;

- оцінка ефективності.

На початковому етапі проектування програми виховання педагогічна діяльность розробників базується на вихідних принципах, які включають: системність, доступність, варіативності, партнерство, інтеграцію, динаміку розвитку, зв'язок із життям, урахування вікових та індивідуальних особливостей учнів, оптимальності у вибір форм і методів роботи, а також засадах особистісно зорієнтованого, діяльнісного та компетентнісного підходів. За орієнтир для продумування приблизної структури змісту можна обрати наступні аспекти: закладі);

- актуальність (особливості виховання в конкретно визначеному

- мета, задачі;

- цільова аудиторія;

- зміст, форми виховання, відповідно до напрямів, розділів або модулів

- основні індикатори та показники результатівреалізації програми;

- прогнозовані результати;

- додатки (кадровезабезпечення, фінансування, календарні планитощо).

Визначення основних характеристик та окреслення просторових меж для програмування виховання в школі потребує: визначення часових меж реалізації програми; місця їі реалізації (заклад загальної середньої освіти самостійно або у співпраці з іншими освітніми установами, наприклад позашкільним закладом освіти, спортивною школою, підлітковим клубом тощо); вікова категорія здобувачів освіти (учасниками програми є всі учні 33СО, обдаровані діти, діти, які потребують особливої уваги інше) та ін.

Вихідним моментом укладання програми $є$ чітко сформульована мета. Виконання програмного змісту діяльності стає рухом до поставленої мети. Темпи руху i міра досягнення мети залежить від конкретних обставин конкретного закладу. Оскільки загальний характер мети полягає у всебічному розвитку особистості, то слід враховувати, що кожна дитина неповторна, іiі внутрішній світ є автономним. Важливо розуміти той факт, що життя дитини відбувається на засадах інформаційної цивілізації (утилітарні потреби, постійні зміни) і на засадах духовних цінностей, які мають однаковий вплив на неї. 
Журнал«Герспективитаінновації наукиљ

(Серія «Гедагогіка», Серія«Гцихологія», Серія«Медицина»

№5(5) 2021

Тому програма виховання покликана забезпечити позитивну динаміку розвитку особистості школяра, яка виявляється у наступному: здобуття знань основних норм громадянського суспільства на основі цінностей; розвиток позитивних ставлень до суспільних цінностей та на їх основі засвоєння досвіду застосування сформованих знань і ставлень у практичній діяльності[3, 11]. Розуміння таким чином мети дозволяє забезпечити цілісність виховної програми, враховуючи усі важливі сфери шкільного життя. Особистість вільна у виборі $є$ провідною ідеєю програми та центром педагогічної діяльності щомоментно, чи то на уроці, чи в позаурочному процесі.

Слід пам'ятати, що мета - це конкретний, схарактеризований якісно, а де можливо і кількісно, образ бажаного результату, який має бути досягнутий до чітко визначеного терміну, тому іï формулювання має бути чітке, коротке, повне та логічно коректне.

Під результатом програми розуміємо безпосередній підсумок участі кожного учня в діяльності (розвиток особистості), що окреслює три рівні цілей:

1) здобуття учнем соціальних знань (суспільні норми), первинне розуміння соціальної реальності та повсякденного життя;

2) отримання досвіду переживання та позитивного ставлення до базових цінностей суспільства (людина, родина, батьківщина, природа, світ, праця тощо), ціннісного ставлення до соціальної реальності в цілому;

3) отримання досвіду самостійної суспільної дії, що дозволяє стати особистістю, громадянином (взаємодія з соціальними суб'єктами в просторі закладу освіти) здатною до самореалізації в умовах власного вибору.

Ключова умова досягнення результатів реалізації програми полягає у створенні безпечного середовища (оточення), що включає рівень школи, класу (безпечне соціальне середовище), де учень отримує знання, апробує їх та здобуває досвід, який або поціновує та присвоює, або відкидає.

Мета програми виховання конкретизується завданнями, за допомогою яких можна фіксувати проміжні результати іiі реалізації. Вони складають послідовність їі розділів, де кожний наступний цілком пов'язаний з попереднім. Задачі потрібно формулювати так, щоб їх виконання можна було зафіксувати по завершенні. Вони повинні відображати конкретні часові межі, бути реально досяжними, але разом 3 тим орієнтованими на максимально позитивний результат діяльності по завершенні.

У процесі добору завдань важливо враховувати актуальні виклики та проблеми сьогодення, які покликана вирішувати програма; найбільш гострі протиріччя між вимогами соціокультурного розвитку суспільства та рівнем розвитку здобувачів освіти; іiі місце в системі виховної роботи школи; перелік актуальних проблем виховання притаманних для конкретно взятого закладу, які можна вирішити засобами програми; особливості виховного потенціалу закладу, учнівської та педагогічної спільноти; вивчити ресурсні можливості суб’єктів освітнього простору школи, які здатні підсилити ефективність виховної системи школи та ін. 
Головний компонент програми виховання - це іiі зміст. Специфічні характеристики соціокультурного середовища, в якому функціонує школа обумовлюють необхідність включення тих чи інших розділів (блоків) на основі існуючих виховних ресурсів для реалізації завдань визначених програмою та тих, які потрібно розробити.

Зміст програми і механізми іï реалізації розробляють відповідно до мети і завдань. Зміст розкриває спектр основних дій описаних в іiі розділах (модулях), через які школа може здійснювати цілеспрямований процес виховання. Наприклад: класне керівництво, урок, співпраця з батьківською спільнотою, волонтерський напрям, учнівське самоврядування, загальношкільні колективно творчі справи, проекти, шкільні медіа, робота клубів, гуртків та ін. або за наскрізними лініями відповідно до вікових періодів («Екологічна безпека та сталий розвиток» «Громадянська відповідальність» «Здоров'я і безпека», «Підприємливість і фінансова грамотність»).

Важливою умовою добору різних форм виховання $є$ діяльнісний характер. Він наповнює зміст програми реальними активними практиками, які витіснять стереотипи авторитарного виховання та позитивно вливають на перехід до планування та проведення різноманітних ефективних форм роботи разом із учнями, де вони стають ініціаторами та активними учасниками подій. Ключовою ідеєю у означеній діяльності стає не кількість заходів, а те які стосунки склалися в учнівській спільноті, які емоції переживають школярі разом із педагогами, який зміст їхньої спільної діяльності. Таким чином, саме діяльнісний підхід забезпечує можливість ефективного вмотивованого включення учасників освітнього процесу в події шкільного життя та сприяє профілактиці агресивних прояві поведінки та конфліктів.

За ключову категорію у визначенні змістового наповнення пропонуємо обрати соціокультурний досвід школяра. Його розуміємо як апробовані особистістю на власному досвіді норми та способи взаємодії, отримані імперичним шляхом i підтверджені практикою знань, а також ціннісні установки у порівнянні з цінностями суб'єктів соціокультурного простору.

Опосередкований педагогічний вплив дозволяє створювати умови для розвитку особистості, педагогізувати середовище, а також здійснювати педагогічний супровід дитини в освоєнні нею освітнього середовища на принципах тьюторства.

Таким чином, зміст програми скеровує педагогічну діяльність на створення умов в освітньому процесі, які забезпечуватимуть здобуття учнями базових компетентності через формування ціннісної сфери особистості у діяльності, а саме:

- досвіду прийняття рішень в ситуації морального вибору;

- виявлення позитивних зразків самореалізації в особистостісній та соціально- громадсько значимій діяльності;

- успішній самореалізації в пізнавальній, творчій, ігровій діяльності. 
Журнал«Герспективитаінновації науки

(Серія«Гедагогіка», Серія«ГТихологія», Серія «Медицина»

№5(5) 2021

- досвіду реалізації різнорольових позицій: активного учасника, організатора, консультанта та ін;

- застосування отриманих в процесі навчання знань, умінь, навичок в соціально значимій діяльності;

- оцінювання поведінки людей в різних життєвих ситуаціях, що відображають їхні особистісні якості та досвід самооцінки у порівнянні 3 оцінками дорослих, та однолітків;

- партнерської співпраці з дорослими та однолітками;

- проектування власної діяльності, прогнозування та послідовний аналіз іiі результатів;

- вибір власної траєкторії розвитку та шляхів їі досягнення тощо.

Визначені учасниками освітнього процесу цінності та мета виховання мають обов'язково бути відображені у розроблених та затверджених внутрішньо шкільних нормативних актах школи (Стратегія розвитку 33СО, Положення про учнівське самоврядування, Кодекс шкільної етики тощо).

Ще одним важливим фактором, який позитивно впливає на досягнення педагогічної мети у вихованні $\epsilon$ те, що створюючи програму виховання ми моделюємо виховну діяльність, а не особистість дитини, тому добір інструментарію для вимірювання результатів стосується досягнень у контексті здобуття базових компетентностей, а не оцінки особистісних якостей. Саме така позиція забезпечує перехід від стандартизації виховання до створення ресурсів для вільного розвитку школяра. Таким чином, ми проектуємо умови розвитку особистості, а не саму особистість, що за визначення I. Беха $є$ основою особистісно орієнтованого виховання. (БЕХ)

Останнім етапом розроблення програми виховання стає опис основних напрямів самоаналізу, який становить складову внутрішнього контролю забезпечення якості освіти у закладі освіти. Добір інструментарію спрямований визначення результатів якості виховного процесу та конкретні досягнення учнів у сфері вчинкової діяльності щодо здобуття ними базових компетентностей визначених чинним освітнім законодавство. Його результати спрямовані на виявлення проблем у взаємодії всіх учасників; встановлення причин неефективності певних форм роботи; вироблення пропозицій щодо внесення найбільш конструктивних змін у процес виховання; корекцію програм, планів щодо оптимізації подальшого процесу педагогічної дії, подальший розвиток професійної компетентності педагогічних працівників.

Висновок. Програма виховання є своєрідною нормою виховання в окремо взятій школі. Вона окреслює сутність та особливості виховання у сучасній школі як гнучкої системи, яка включає опис різноманітних форм та засобів спільної діяльності дорослих та учнів на принципах партнерства.

Розроблення програми дозволить позбутися проблем імітації та бюрократизації рутинних традицій. Її основними характеристиками має статигнучкість, оптимальність, доступність, демократичність та системність. 
Також, пропонуємо у процесі розроблення програми виховання будь-якого закладу освіти враховувати наступне:

- особливості виховного процесу (геолокацію, соціальне оточення, джерела позитивного та негативного впливу на учнів, можливих партнерів, опис учнівського контингенту, оригінального досвіду школи, традицій, принципів виховання); окремо визначеної школи;

- мету $i$ завдання виховання (початкова школа - створення сприятливих умов для здобуття знань базових норм та традицій суспільства; середня школа - розвиток ціннісних ставлень до себе, родини, школи, національної культури, природи тощо; старша школа - особлива увага спрямовується на здобуття досвіду участі в соціально значимих справах, формуванню соціальної та громадянської компетентності);

- види, форми та зміст діяльності(опис способів досягнення цілей та завдань виховання у контексті обраних напрямів, модулів або наскрізних ліній, які корелюють 3 освітніми програми школи); основні напрями самоаналізу якості змісту виховного процесу (складова внутрішнього контролю забезпечення якості освіти, визначає напрямів самоаналізу, який має на меті виявлення основних проблем шкільного виховання та їх усунення). За потреби кожна школа може розширювати змістове наповнення програми. Слід розуміти, що сама програма не $\epsilon$ інструментом виховання учнів. Вона лише окреслює систему способів діяльності, які дозволяють педагогу скоординувати свої зусилля, спрямовані на особистісний розвиток учнів.

\section{Лimepamypa}

1. Бех І.Д. Особистість на шляху до духовних цінностей :монографія. / І.Д. Бех. - Київ - Чернівці : «Букрек», 2018. - 320 с.

2. Вишневський, О.І. Теоретичніосновисучасноїукраїнськоїпедагогіки :навч. посіб. / ОмелянВишневський. - Вид. 2-ге, доопрац. і доп. - Дрогобич: Коло, 2006. - 326 с.

3. Воспитание в современной школе: от программы к действиям. Методическое пособие / П. В. Степанов, Н. Л. Селиванова, В. В. Круглов, И. В. Степанова, И. С. Парфенова, И. Ю. Шустова, Е. О. Черкашин, М. Р. Мирошкина, Т. Н. Тихонова, Е. Ф. Добровольская, И. Н. Попова; под ред. П. В. Степанова. - М. : ФГБНУ «ИСРО РАО», 2020. $-119 \mathrm{c}$.

4. Гавлітіна Т. Наскрізне виховання цінностей у Новій українській школі / Т. Гавлітіна // Нова педагогічна думка. - 2020. - № 2. - С. 141-145. URL: http://nbuv.gov.ua/UJRN/Npd_ 2020_2_33(дата звернення 10.11.2021)

5. Закон України «Про освіту» від 05.09.2017 p. № 2145-VIII. Ст. 1-7. URL: http://zakon.rada.gov/lavs/show/2145-19 (дата звернення: 05.11.2021)

6. Концепція Нової української школи. URL: https://www.kmu.gov.ua/storage/app/ media/reforms/ukrainska-shkola-compressed.pdf

7. Кремень В.Г. Про «Дитиноцентризм», або Чому освіта України потребує структурних змін / В. Кремень // Щоденна всеукраїнська газета «День». - № 210(3130). - 19 листопада, 2009. - С. 1-6

8. Основні оріснтири виховання учнів 1-11 класів загальноосвітніх навчальних закладів України URL: https://osvita.ua/legislation/Ser_osv/24565/

9. Програма «Нова українська школа» у поступі до цінностей. URL: https://ipv.org.ua/prohrama-novaukrainska-shkola/ (дата звернення 25.11.2021) 
10. Перспективные модели воспитания школьников и студентов: сб. статей / под ред. Н. Л. Селивановой. М.: ФБГНУ РАО, 2015. 212 с.

11. Степанов П. В. Структура и содержание примерной программы воспита- ния // Отечественная и зарубежная педагогика. 2020. Т. 2, №1 (67). С. 41-47

\section{References:}

1. Bekh I.D. (2018). Osobistist' na shlyahu do duhovnih cinnostej :monografiya [ Personality on the way to spiritual values] Kiïv- Chernivci: «Bukrek»[in Ukrainian].

2. Vishnevs'kij, O.I. (2006). Teoretichni osnovi suchasnoï ukraïns'koï pedagogiki :navch. posib. [Theoretical foundations of modern Ukrainian pedagogy]. Drogobich: Kolo [in Ukrainian].

3. Stepanov, P. V.,. Selivanova, N. L., Kruglov, V. V., Stepanova, I. V., Parfenova, I. S., Shustova, I. Yu. «et al.» (2020). Vospitanie v sovremennoj shkole: ot programmy $k$ dejstviyam. [Education in a modern school: from program to action]. Moskva. : FGBNU «ISRO RAO» [in Rossiya].

4. Gavlitina, T. (2020). Naskrizne vihovannya cinnostej u Novij ukraïns'kij shkoli [Naskrizne vihovannya cinnostej u Novij ukraïns'kij shkoli.]. Nova pedagogichna dumka, I, 141-145 [in Ukrainian].

5. Zakon Ukraïni Pro osvitu: prijnyatij 5 ver. 2017 roku № 2145-VIII [Law of Ukraine on Education from September 5 2017, № 2145-VIII]. (2017, September 5. Holos Ukrainy - Voice of Ukraine, 178, pp. 10-12 [in Ukrainian]

6. Koncepciya "Nova ukraïns'ka shkola» [Concept of the "New Ukrainian School"]. Retrieved from https://www.kmu.gov.ua/storage/app/media/reforms/ukrainska-shkola-compressed.pdf

7. Kremen,' V.G. (2009). Pro «Ditinocentrizm», abo Chomu osvita Ukraïni potrebu€ strukturnih zmin ["Child-centeredness", or Why education in Ukraine needs structural change]. Shchodenna vseukraïn'ka gazeta "Den'» - Daily All-Ukrainian newspaper "Day", 2009_210(3130)_1_6. [in Ukrainian].

8.Osnovni orientiri vihovannya uchniv 1-11 klasiv zagal'noosvitnih navchal'nih zakladiv [The main guidelines for the education of students in grades 1-11 of secondary schools in Ukraine ] Retrieved from http://base.garant.ru/12145525/ [in Ukrainian]

9. Programa «Nova ukraïns'ka shkola» u postupi do cinnostej. [The program "New Ukrainian School" in the progress of values] Retrieved from: https://ipv.org.ua/prohrama-novaukrainska-shkola/

10.Selivanovoj, . N. L.(2015). Perspektivnye modeli vospitaniya shkol'nikov $i$ studentov: sb. Statej [Promising models of education of schoolchildren and students] Moskva..: FBGNU RAO [in Rossiya].

11.Stepanov, P. V. (2020). Struktura i soderzhanie primernoj programmy vospita- niya[The structure and content of an exemplary educational program]. Otechestvennaya i zarubezhnaya pedagogika - Domestic and foreign pedagogy, 1 (67) [in Rossiya]. 